\title{
PENGETAHUAN, PENDIDIKAN DAN PERSEPSI IBU HAMIL DALAM PENGGUNAAN BUKU KESEHATAN IBU DAN ANAK (KIA) DI DESA KUNGKAI WILAYAH KERJA PUSKESMAS BANGKO
}

\author{
Revinovita

\begin{abstract}
Dosen Kebidanan, STIKes Merangin Jl. Bangko-Keinci KM 06 Kungkai Kecamatan Bangko Kabupaten Merangin revinovita@ymail.com
\end{abstract}

\begin{abstract}
Abstrak: Prioritas utama pembangunan kesehatan di Indonesia salah satunya adalah program Kesehatan Ibu dan Anak (KIA). Indonesia memiliki sebanyak 4,5 juta Buku KIA telah tersedia dan terdistribusi untuk ibu hamil dan bayi. Penelitian ini bertujuan untuk mengetahui faktor-faktor penggunaan buku KIA pada ibu hamil di Desa Kungkai Wilayah Kerja Puskesmas Bangko Tahun 2018. Penelitian ini adalah penelitian analitik, desain cross sectional, dilakukan di Desa Kungkai bulan Agustus 2018. populasi seluruh ibu hamil di Desa Kungkai dengan jumlah sampel 83 orang. Instrumen yang digunakan kuesioner dengan analisa Chi-Square. Hasil penelitian ada hubungan antara pengetahuan dengan penggunaan buku KIA, ada hubungan antara pendidikan dengan penggunaan buku KIA, ada hubungan antara persepsi dengan penggunaan buku KIA. Diharapkan bagi Puskesmas Bangko untuk dapat meningkatkan pengetahuan ibu hamil tentang penggunaan buku KIA melalui pemberian penyuluhan.
\end{abstract}

Kata Kunci: Pengetahuan, Pendidikan, Persepsi, Penggunaan Buku KIA.

\begin{abstract}
One of the main priorities in health development in Indonesia is the Maternal and Child Health $(\mathrm{MCH})$ program. Indonesia as many as 4.5 million $\mathrm{MCH}$ Handbooks have been available and distributed for pregnant women and infants. This study aims to determine the factors associated with the use of the Book $\mathrm{MCH}$ in pregnant women in the Kungkai Village Bangko Health Center Work Areas in 2018. This study is an analytic study, with a cross sectional design, conducted in Kungkai Village in August 2018. the population of all pregnant women in Kungkai Village with a total sample of 83 people. The instrument used was a questionnaire with Chi-Square analysis. The results of the study there was a relationship between knowledge and the use of $\mathrm{MCH}$ books, there was a relationship between education and the use of $\mathrm{MCH}$ books, and there was a relationship between perceptions and the use of the MCH book. It is hoped that Bangko Health Center can increase the knowledge of pregnant women about the use of $\mathrm{MCH}$ books through counseling.
\end{abstract}

Keywords: Knowledge, Education, Perception Use of the MCH Handbook

Program Kesehatan Ibu dan Anak (KIA) merupakan salah satu prioritas utama pembangunan kesehatan di Indonesia. Program ini bertanggung jawab terhadap pelayanan kesehatan bagi ibu hamil, ibu melahirkan, bayi dan neonatal. Salah satu tujuan program ini adalah menurunkan kematian dan kejadian sakit pada ibu dan anak melalui peningkatan mutu pelayanan dan menjaga kesinambungan pelayanan kesehatan ibu dan perinatal di tingkat pelayanan dasar dan pelayanan rujukan primer (Sistiarani, dkk, 2014).

$$
\text { Pemerintah Indonesia telah }
$$

merumuskan beberapa kebijakan untuk menekan Angka Kematian Ibu (AKI) serta 
mendukung peningkatan kesehatan dan kelangsungan hidup ibu dan bayi baru lahir. Pemerintah juga telah membentuk beberapa kebijakan tentang pelaksanaan pelayanan kesehatan ibu dan anak salah satunya dengan menggunakan buku KIA sebagai pencatatan pelayanan ibu dan anak serta bahan informasi kesehatan bagi ibu dan keluarga (Oktarina, dkk, 2013).

Buku KIA adalah buku yang berisi catatan kesehatan ibu (hamil, bersalin dan nifas) dan anak (bayi baru lahir sampai anak usia 6 tahun) serta berbagai informasi cara memelihara dan merawat kesehatan ibu dan anak (Kemenkes RI, 2016).

Penggunaan buku KIA merupakan salah satu media yang dapat digunakan sebagai alternatif dalam pemberdayaan masyarakat terutama keluarga untuk memelihara kesehatannya dan mendapatkan pelayanan kesehatan ibu dan anak yang berkualitas. Buku KIA berisi informasi dan materi penyuluhan tentang gizi dan kesehatan ibu dan anak, kartu ibu hamil, KMS balita dan catatan pelayanan kesehatan ibu dan anak (Nurhayati, dkk, 2013).

Selain faktor risiko ibu hamil, tanda bahaya pada persalinan, nifas dan bayi baru lahir sampai balita dapat diketahui dan terdeteksi secara dini oleh tenaga kesehatan melalui buku KIA. Tanda bahaya pada persalinan yang dapat diketahui melalui buku KIA antara lain, pendarahan lewat jalan lahir, persalinan sungsang, eklampsi (kejang), air ketuban keruh dan berbau, ibu gelisah dan sakit yang berlebihan, dan tanda bahaya ibu nifas yang dapat diketahui melalui buku KIA antara lain, pendarahan lewat jalan lahir, keluar cairan berbau dari jalan lahir, edema, kejang, demam lebih dari 2 hari, payudara bengkak, merah disertai rasa sakit dan depresi, sedangkan tanda bahaya pada bayi baru lahir yang dapat dideteksi melalui buku KIA antara lain, bayi tidak mau menyusu, kejangkejang, lemah, sesak nafas, tali pusat kemerahan dan bernanah, demam tinggi, mata bernanah, diare, ikterus dan tinja bayi berwarna pucat, sedangkan pada anak balita, melalui buku KIA tenaga kesehatan dapat memantau kondisi penyimpangan tumbuh kembang balita dan kecukupan gizi balita (Kemenkes RI, 2016).

Berdasarkan data yang diperoleh dari Kementerian Kesehatan Republik Indonesia Tahun 2013 dalam Oktarina (2013), diketahui bahwa penyediaan dan distribusi buku Kesehatan Ibu dan Anak (buku KIA) di Indonesia sebanyak 4,5 juta untuk ibu hamil dan bayi di Indonesia.

Peningkatan implementasi buku KIA didukung oleh pemerintah pusat sebagai salah satu program untuk meningkatkan kesehatan ibu dan anak, menuntun petugas kesehatan dalam memberikan pelayanan kesehatan ibu dan anak sesuai standar, melakukan dokumentasi secara baik dan 
benar, serta merupakan satu-satunya bukti yang dipegang ibu sebagai dokumentasi status kesehatannya selama hamil, bersalin, nifas, imunisasi dan tumbuh kembang balita, sehingga mempermudah ibu dan keluarga serta petugas kesehatan mengetahui riwayat kesehatan ibu dan anak. Namun, pada pelaksanaannya buku KIA belum dimanfaatkan sebagaimana semestinya, masih banyak ibu hamil dan keluarga yang belum mengerti dan tidak menerapkan informasi kesehatan yang terdapat di dalam buku KIA (Kemenkes, 2015 dalam Ainiyah, dkk, 2017).

Pengetahuan ibu adalah penting sebagai dasar untuk mengubah perilaku. karena dengan pengetahuan yang baik akan menambah memahami dan mengerti isi buku KIA tersebut.Rendahnya pengetahuan ibu tentang penggunaan buku KIA menjadi kendala dalam pelayanan kesehatan ibu dan anak, anggapan yang keliru tentang buku KIA yang hanya digunakan sebagai buku catatan pemeriksaan kehamilan saja. Sehingga pentingnya pengajaran isi buku KIA oleh tenaga kesehatan terhadap ibu hamil dan ibu bayi, (Oktarina, dkk, 2013).

Pengetahuan yang baik tentang buku KIA akan dapat meningkatkan kepatuhan ibu dalam penggunaan buku KIA. Pengetahuan ibu mengenai buku KIA antara lain tentang apa tujuan diberikannya buku KIA, fungsi buku KIA, manfaat buku
KIA serta manfaat dari penggunaan buku KIA (Sistiarani, dkk, 2014).

Berdasarkan survei awal yang peneliti lakukan di Desa Kungkai Wilayah Kerja Puskesmas Bangko tahun 2018, peneliti melakukan wawancara kepada bidan desa. dari 83 ibu hamil yang memiliki buku KIA hanya 22 orang ibu hamil yang membawa buku KIA saat melakukan pemeriksaan kehamilan dengan bidan desa di Desa Kungkai. Berdasarkan data yang diperoleh dari Desa Kungkai Wilayah Kerja Puskesmas Bangko juga didapatkan satu kasus kematian ibu yang diakibatkan karena perdarahan post partum pada tahun 2017.

\section{BAHAN DAN CARA KERJA}

Jenis penelitian ini adalah penelitian analitik dengan desain cross sectional yang bertujuan untuk mengetahui hubungan pengetahuan, pendidikan dan persepsi ibu hamil tentang penggunaan KIA di Desa Kungkai Wilayah Kerja Puskesmas Bangko tahun 2018.

Penelitian ini telah dilaksanakan di Desa Kungkai Wilayah Kerja Puskesmas Bangko. Populasi adalah keseluruhan objek penelitian atau objek yang diteliti (Notoatmodjo, 2012). Berdasarkan pengertian tersebut, maka populasi dalam penelitian ini adalah seluruh ibu hamil yang ada di Desa Kungkai Wilayah Kerja 
Puskesmas Bangko tahun 2018 yang berjumlah 33 orang.

Variabel adalah sesuatu yang digunakan sebagai ciri, sifat atau ukuran yang dimiliki atau didapatkan oleh satuan penelitian tentang sesuatu konsep pengertian tertentu (Notoatmodjo, 2012).

Adapun variabel dalam penelitian ini adalah variabel independen yaitu pengetahuan, pendidikan dan persepsi. Variabel dependen yaitu penggunaan buku Kesehatan Ibu dan Anak (KIA). Instrumen penelitian yang digunakan dalam penelitian ini adalah kuesioner, yang berisikan pertanyaan yang berhubungan dengan hubungan pengetahuan, pendidikan dan persepsi ibu hamil tentang penggunaan buku Kesehatan Ibu dan Anak (KIA) di Desa Kungkai Wilayah Kerja Puskesmas Bangko tahun 2018. Pengumpulan data dalam penelitian ini adalah data primer yang diperoleh dengan melakukan wawancara langsung kepada responden dengan bantuan kuesioner.

\section{HASIL}

\section{Hubungan Pengetahuan Ibu Hamil Tentang Penggunaan Buku KIA}

Tabel 1. Hubungan Pengetahuan Ibu Hamil Tentang Penggunaan Buku KIA di Desa Kungkai Wilayah Kerja Puskesmas Bangko Tahun 2018

\begin{tabular}{llcccc}
\hline \multirow{2}{*}{$\begin{array}{c}\text { N } \\
\text { o }\end{array}$} & Pengetahuan & \multicolumn{2}{c}{$\begin{array}{c}\text { Penggunaan } \\
\text { Buku KIA }\end{array}$} & Jml & $\begin{array}{c}\mathbf{x}^{2} \\
\text { hitung }\end{array}$ \\
\cline { 3 - 4 } & & Iya & tidak & & \\
\hline 1 & Baik & 5 & 7 & 12 & \multirow{2}{*}{7,095} \\
2 & Cukup & 7 & 8 & 15 & \\
3 & Kurang & 10 & 46 & 56 & \\
\cline { 1 - 4 } & Jumlah & 22 & 61 & 83 & \\
\hline
\end{tabular}

Tabel di atas diketahui bahwa dari 83 ibu hamil yang diteliti ternyata ditemukan ibu hamil yang memiliki pengetahuan baik sebanyak $12(14,46 \%)$ ibu hamil tentang penggunaan buku KIA di Desa Kungkai Wilayah Kerja Puskesmas Bangko tahun 2018. Hasil analisis Chi-Square menunjukkan ada hubungan antara pengetahuan dengan penggunaan buku KIA.

Menurut asumsi peneliti, pengetahuan ibu hamil berhubungan dengan penggunaan buku Kesehatan Ibu dan Anak (KIA). Hal ini dikarenakan berdasarkan hasil penelitian didapatkan seluruh ibu hamil memiliki pengetahuan kurang tentang penggunaan buku Kesehatan Ibu dan Anak (KIA). Pengetahuan yang kurang membuat ibu hamil kurang memahami secara benar tentang isi dari buku Kesehatan Ibu dan Anak (KIA) khususnya tentang tanda-tanda bahaya pada kehamilan, tanda-tanda bahaya pada persalinan dan tanda-tanda bahaya pada ibu nifas.

Pengetahuan merupakan domain yang sangat penting dalam terbentuknya suatu tindakan. Pengetahuan merupakan salah satu faktor yang mempengaruhi perilaku seseorang. Pengetahuan berpengaruh terhadap praktek baik secara langsung atau tidak langsung, melalui perantara sikap (Notoatmodjo, 2010). 
Pengetahuan yang baik tentang buku KIA maka akan dapat meningkatkan pemahaman ibu dalam penggunaan buku KIA. Pengetahuan ibu mengenai buku KIA antara lain tentang pengetahuan ibu mengenai apa tujuan diberikannya buku KIA, fungsi buku KIA serta manfaat dari penggunaan buku KIA (Sistiarani, dkk, 2014).

Pengetahuan ibu akan meningkatkan pemahaman ibu dalam penggunaan buku KIA. Dalam upaya meningkatkan kesehatan ibu dan anak perlu ditingkatkan kembali cakupan pemahaman ibu hamil, tidak hanya tujuan, fungsi dan manfaat saja namun juga seluruh aspek baik aspek persalinan maupun nifas, selain itu diharapkan tidak hanya mengandalkan buku KIA saja namun antara lain dengan cara promosi kesehatan Ibu hamil yang ditangani secara lintas program dan lintas sektoral. Penelitian Emy dkk (2015) menunjukkan bahwa ibu yang mempunyai pemahaman tinggi lebih baik dibanding dengan ibu yang mempunyai pemahaman rendah. Sejalan dengan penelitian Agusrini. (2013) ada Hubungan Pengetahuan Ibu Hamil Tentang Buku KIA Dengan Pemanfaatan Buku KIA.

\section{Hubungan Pendidikan Ibu Hamil Tentang Penggunaan Buku KIA}

Tabel 2. Hubungan Pendidikan Ibu Hamil Tentang Penggunaan Buku KIA di Desa Kungkai Wilayah Kerja Puskesmas Bangko Tahun 2018

\begin{tabular}{lllll}
\hline N & Pendidikan & Penggunaan & Jml & $\mathbf{x}^{2}$
\end{tabular}

\begin{tabular}{cccccc}
\hline $\mathbf{N}$ & & \multicolumn{2}{c}{ Buku KIA } & & hitung \\
\cline { 3 - 4 } $\mathbf{0}$ & & iya & tidak & & \\
\hline 1 & Tinggi & 9 & 6 & 15 & \\
2 & Sedang & 5 & 11 & 16 & 12,124 \\
3 & Rendah & 8 & 44 & 52 & \\
\cline { 1 - 4 } & Jumlah & 22 & 61 & 83 & \\
\hline
\end{tabular}

Tabel di atas diketahui bahwa dari 83 ibu hamil yang diteliti ternyata ditemukan sebagian besar yaitu sebanyak $52(62,65 \%)$ ibu hamil memiliki pendidikan rendah tentang penggunaan buku Kesehatan Ibu dan Anak (KIA) di Desa Kungkai Wilayah Kerja Puskesmas Bangko tahun 2018.

Hasil analisis Chi-Square memperlihatkan $\mathrm{X}^{2}$ hitung $(12,124)>\mathrm{X}_{\text {tabel }}^{2}$ (3,841), maka $\mathrm{H}_{\mathrm{a}}$ diterima dan $\mathrm{H}_{0}$ ditolak yang berarti ada hubungan antara pendidikan dengan penggunaan buku Kesehatan Ibu dan Anak (KIA) di Desa Kungkai.

Menurut hasil penelitian, pendidikan ibu hamil berhubungan dengan penggunaan buku Kesehatan Ibu dan Anak (KIA), hal ini dikarenakan berdasarkan hasil penelitian didapatkan sebagian besar ibu hamil memiliki pendidikan rendah tentang penggunaan buku Kesehatan Ibu dan Anak (KIA) dengan hasil $\mathrm{X}^{2}$ hitung 12,124.

Menurut Azwar (2007) bahwa pendidikan sebagai suatu proses atau kegiatan untuk mengembangkan kepribadian atau kemampuan individu atau masyarakat, ini berarti bahwa pendidikan adalah suatu pembentukan watak disertai kemampuan dalam bentuk kecerdasan, pengetahuan dan keterampilan. Tingkat 
pendidikan sangat menetukan daya nalar seseorang yang lebih baik, sehingga memungkinkan menyerap informasi juga dapat berfikir secara rasional dalam menanggapi informasi atau setiap masalah yang dihadapi.

\section{Hubungan Persepsi Ibu Hamil Tentang Penggunaan KIA}

Tabel 3. Hubungan Persepsi Ibu Hamil Tentang Penggunaan KIA di Desa Kungkai Wilayah Kerja Puskesmas Bangko

\begin{tabular}{llcccc}
\hline \multirow{2}{*}{$\begin{array}{c}\text { N } \\
\text { o }\end{array}$} & \multirow{2}{*}{ Persepsi } & \multicolumn{2}{c}{$\begin{array}{c}\text { Penggunaan } \\
\text { Buku KIA }\end{array}$} & Jml & $\mathbf{x}^{2}$ hitung \\
\cline { 3 - 4 } & & & \\
\cline { 1 - 4 } 1 & Positif & 13 & 10 & 23 & \\
2 & Negatif & 9 & 51 & 60 & \multirow{2}{*}{14,717} \\
\cline { 1 - 4 } & & & & & \\
\hline
\end{tabular}

Tabel di atas diketahui bahwa dari 83 ibu hamil yang diteliti ternyata ditemukan ibu hamil yang memiliki persepsi positif sebanyak $23(27,71 \%)$ ibu hamil dan sebanyak 60 (72,29\%) ibu hamil memiliki persepsi negatif tentang penggunaan buku Kesehatan Ibu dan Anak (KIA) di Desa Kungkai Wilayah Kerja Puskesmas Bangko tahun 2018.

Hasil analisis Chi-Square memperlihatkan $\mathrm{X}^{2}{ }_{\text {hitung }}(14,717)>\mathrm{X}^{2}$ tabel $(3,841)$, maka $\mathrm{H}_{\mathrm{a}}$ diterima dan $\mathrm{H}_{0}$ ditolak yang berarti ada hubungan antara persepsi dengan penggunaan buku Kesehatan Ibu dan Anak (KIA) di Desa Kungkai.

\section{PEMBAHASAN}

Menurut asumsi peneliti, persepsi ibu hamil ada hubungan dengan penggunaan buku Kesehatan Ibu dan Anak (KIA), hal ini dikarenakan berdasarkan hasil penelitian didapatkan sebagian besar ibu hamil memiliki persepsi negatif tentang penggunaan buku Kesehatan Ibu dan Anak (KIA), dan berdasarkan survei awal ditemukan masih banyak ibu hamil di Desa Kungkai Wilayah Kerja Puskesmas Bangko yang tidak menggunakan buku Kesehatan Ibu dan Anak (KIA) dengan baik.

Penggunaan pelayanan kesehatan ibu dan anak masih terkendala oleh rendahnya pengetahuan ibu tentang penggunaan buku KIA, pelayanan KIA dan sampai saat ini masih ada anggapan yang keliru tentang buku KIA, karena hanya dianggap sebagai buku catatan pemeriksaan kehamilan saja. Pengetahuan itu penting sebagai dasar untuk mengubah perilaku. Pentingnya pengajaran isi buku KIA oleh tenaga kesehatan terhadap ibu hamil dan ibu bayi, karena sangat berguna untuk menambah pengetahuan dalam memahami dan mengerti isi buku KIA tersebut (Oktarina, dkk, 2013).

Menurut Kotler (2000) menjelaskan persepsi sebagai proses bagaimana seseorang menyeleksi, mengatur dan menginterprestasikan masukan-masukan informasi untuk menciptakan gambaran keseluruhan yang berarti.

Notoatmodjo (2003) dalam Wawan, dkk (2010), menyatakan bahwa pengetahuan merupakan domain yang sangat penting untuk terbentuknya tindakan 
seseorang (ovent behavior). Dari pengalaman dan penelitian ternyata perilaku yang didasari oleh pengetahuan akan lebih langgeng daripada perilaku yang tidak didasari oleh pengetahuan. Sebagaimana penelitian Ainiyah, dkk. (2017) ada Hubungan Pemanfaatan Buku Kesehatan Ibu dan Anak (KIA) Dengan Tingkat Pengetahuan dan Perilaku Kesehatan Ibu Hamil Trimester III di Puskesmas Jagir Surabaya.

\section{KESIMPULAN}

Berdasarkan hasil penelitian tentang hubungan pengetahuan, pendidikan dan

\section{DAFTAR RUJUKAN}

Agusrini. (2013). Hubungan Pengetahuan Ibu Hamil Tentang Buku KIA Dengan Pemanfaatan Buku KIA di Puskesmas Srondol Kota Semarang Tahun 2013.

Ainiyah, dkk. (2017). Hubungan Pemanfaatan Buku Kesehatan Ibu dan Anak (KIA) Dengan Tingkat Pengetahuan dan Perilaku Kesehatan Ibu Hamil Trimester III di Puskesmas Jagir Surabaya Tahun 2017.

Emy Yuliantini,dkk. (2015) Hubungan Pemahaman Ibu tentang Pesan Gizi Seimbang dengan Status gizi Anak Prasekolah di TK IT Auladuna Kota Bengkulu, Journal Gizi Indonesia Vol. 38, No.2(2015)

Farida. (2015). Determinan Pemanfaatan Buku Kesehatan Ibu dan Anak (KIA) Oleh Ibu Hamil di Puskesmas Wanakerta Kabupaten Karawang Tahun 2015.

Kemenkes RI. (2016). Buku Kesehatan Ibu dan Anak. Jakarta: Kementerian Kesehatan dan JICA (Japan International Cooperation Agency).

Kurniasari. (2017). Buku KIA dan Pemanfaatan Untuk Peningkatan Kesehatan Ibu dan Anak Tahun 2017.

Musdalina. (2015). Hubungan Karakteristik dan Persepsi Ibu Tentang Buku Kesehatan Ibu dan Anak (KIA) Dengan Pemanfaatan Buku KIA Pada Pelayanan Antenatal Care (ANC) di Wilayah Kerja Puskesmas Stabat Kecamatan Stabat Kabupaten Langkat Tahun 2015. persepsi ibu hamil tentang penggunaan buku Kesehatan Ibu dan Anak (KIA) di Desa Kungkai Wilayah Kerja Puskesmas Bangko tahun 2018 dapat diambil kesimpulan ada hubungan pengetahuan, pendidikan ibu hamil dan persepsi ibu hamil dengan penggunaan buku Kesehatan KIA di Desa Kungkai Wilayah Kerja Puskesmas Bangko tahun 2018.Ada hubungan pendidikan ibu hamil dengan penggunaan buku KIA di Desa Kungkai Wilayah Kerja Puskesmas Bangko tahun 2018.

Nasir, dkk. (2011). Buku Ajar Metodologi Penelitian Kesehatan. Yogyakarta: Nuha Medika.

Notoatmodjo. (2007). Promosi Kesehatan Dan Ilmu Perilaku. Jakarta: Rineka Cipta.

(2012). Metodologi Penelitian Kesehatan. Jakarta: Rineka Cipta.

Nurhayati, dkk. (2013). Faktor Yang Mempengaruhi Peran Kader Dalam Penggunaan Buku Kesehatan Ibu dan Anak di wilayah kerja Puskesmas Kalibagor Kabupaten Banyumas Tahun 2013.

Oktarina, dkk. (2013). Hubungan Pengetahuan, Sikap, Kepatuhan Ibu Hamil dan Ibu Bayi Dalam Penggunaan Buku KIA di Puskesmas Geger dan Kedundung Kabupaten Bangkalan, Jawa Timur Tahun 2013.

Purnami, dkk. (2007). Hubungan Persepsi Ibu Tentang Sarana Pelayanan KIA Dengan Kunjungan Pemeriksaan Kehamilan (K4) di Wilayah Kerja Puskesmas Tegal Barat II Kota Tegal Tahun 2007.

Rismalinda. (2015). Buku Ajar Asuhan Kebidanan Kehamilan. Jakarta: Trans Info Media.

Ristrini, dkk. (2013). Upaya Peningkatan Deteksi Dini Risiko Tinggi Kehamilan Melalui Kelengkapan Pengisian Buku KIA Oleh Bidan di Kabupaten Bangkalan Jawa Timur Tahun 2013.

Sistiarani, dkk. (2014). Analisis Kualitas Penggunaan Buku Kesehatan Ibu dan Anak di Wilayah Kerja Puskesmas Kalibagor Tahun 2014. 
072 Jurnal Media Kesehatan, Volume 12 Nomor 2, Desember 2019, hlm. 065-072

Wawan, dkk. (2010). Teori Dan Pengukuran Pengetahuan, Sikap, dan Perilaku Manusia. Yogyakarta: Nuha Medika.

Yanti. (2017). Konsep Dasar Asuhan Kehamilan. Bandung: Refika Aditama.

Yuliani, dkk. (2017). Buku Ajar Aplikasi Asuhan Kehamilan Ter-Update, Disertai Program
Pemerintah Berkaitan Dengan Antenatal Care. Jakarta: Trans Info Media.

Yusriana. (2017). Faktor-Faktor Yang Mempengaruhi Kejadian Perdarahan Post Partum di RSU PKU Muhammadiyah Bantul Tahun 2017. 